\title{
Health risk assessment of heavy metals in vegetables grown around battery production area
}

\author{
Ying Chen, Pingping Wu, Yufang Shao*, Yibin Ying
}

Zhejiang University/School of Biosystems Engineering and Food Science - 310058 Hangzhou - PR China.

*Corresponding author <shaoyf@zju.edu.cn>

Edited by: Leônidas Carrijo Azevedo Melo

Received June 21, 2013

Accepted September 27, 2013
ABSTRACT: Battery production is one of the main sources of heavy metals that present great harm to human health even in low concentrations. Chromium (Cr), Cadmium (Cd) and Lead (Pb) were measured in edible portions of vegetables and soils around a battery production area in China, and the potential health risk of heavy metal contamination to the local population via vegetable consumption was evaluated. Their concentrations in edible portions of vegetables were $2.354(0.078-14.878), 0.035(0.003-0.230)$ and $0.039(0.003-0.178) \mathrm{mg} \mathrm{kg}^{-1}$, respectively. Approximately $3 \%$ of the $\mathrm{Cd}$ in the vegetable samples exceeded the maximum concentration allowable by national food safety criteria, although $\mathrm{Pb}$ content in all samples were within the criteria. Transfer factors (TF) from soils to vegetables were dependent on vegetable species. Leguminous vegetables were more likely to accumulate $\mathrm{Cr}$, while leaf vegetables tended to show higher levels of concentration of $\mathrm{Cd}$ and $\mathrm{Pb}$. Melon vegetables demonstrated a relatively low capacity for accumulating the heavy metals studied. TF were positively correlated with soil organic matter and negatively correlated with soil $\mathrm{pH}$. The mean estimated daily intake of $\mathrm{Cr}$, $\mathrm{Cd}$ and $\mathrm{Pb}$ via dietary consumption of vegetables was $0.011,1.65 \times 10^{-4}$ and $1.84 \times 10^{-4} \mathrm{mg}$ $\mathrm{kg}^{-1}$ of body weight per day, respectively, levels that were much lower than the reference doses recommended by USEPA (U.S. Environmental Protection Agency) and JECFA (Joint FAO/WHO Expert Committee on Food Additives), indicating that the potential health risk of $\mathrm{Cr}, \mathrm{Cd}$ and $\mathrm{Pb}$ exposure via vegetable consumption to the local population around this battery production area could be negligible.

\section{Introduction}

Heavy metals can be very harmful to the human body even in low concentrations as there is no effective excretion mechanism (Ghosh et al., 2012). Lead $(\mathrm{Pb})$ gives rise to adverse effects in several organs and systems in all known animal species, such as the blood, central nervous system, kidneys, reproductive and immune systems (NCM, 2003). Cadmium (Cd) is persistent and accumulates mainly in the kidney and liver of vertebrates, producing severe diseases in these organs (UNEP, 2006). Chromium ( $\mathrm{Cr}$ ) can cause skin ulcers and nasal septum perforations (USEPA, 1980).

While both $\mathrm{Cr}$ (III) and $\mathrm{Cr}$ (VI) can be toxic to plants and animals, $\mathrm{Cr}$ (III) toxicity occurs in higher concentrations, and this form is actually an essential nutrient to human and other animals. $\mathrm{Cr}$ (VI), on the other hand, is toxic in much lower concentrations and also tends to be more mobile and bioavailable than $\mathrm{Cr}$ (III) in surface and subsurface environments (Adriano, 2001). Compared with other pathways such as inhalation and dermal contact, dietary intake is the main route of exposure to heavy metals for most people (Tripathi et al., 1997; Qian et al., 2010; Yeganeh et al., 2012).

Battery production is one of the main sources of heavy metals, yet some battery production areas have not been carefully monitored. In this study, the heavy metal pollution around Changxing County, a famous lead-acid battery production base located in the north of Zhejiang Province, China, was investigated. Started in 1970s, lead-acid battery production brought about serious environmental problems, especially heavy metal pollution. Extensive studies have focused on the assessment of potential health risks associated with exposure to heavy metals via vegetable consumption for residents in the vicinity of mining and smelting sites ( $\mathrm{Li}$ et al., 2006; Sipter et al., 2008; Cao et al., 2010; Liu et al., 2010; Dong et al., 2011; Wang et al., 2011; Xiao et al., 2011; ).

Some studies have been carried out to assess the health risk of heavy metals through consuming vegetables from sewage-irrigated areas (Avci, 2012; Ghosh et al., 2012; Wang et al., 2012; Weldegebriel et al., 2012; Xue et al., 2012). To our knowledge. few studies have been carried out that have analyzed heavy metals in agro-products and evaluated potential health risks to inhabitants around battery production areas. Therefore, the main objective of this work is to determine the contamination levels of $\mathrm{Cr}, \mathrm{Cd}$ and $\mathrm{Pb}$ in selected vegetables and to evaluate the health risk to the local population via consumption of vegetables.

\section{Materials and Methods}

\section{Study area}

Changxing County $\left(30^{\circ} 43^{\prime}-30^{\circ} 11^{\prime} \mathrm{N}, 1^{\prime} 19^{\circ} 33^{\prime}-\right.$ $120^{\circ} 06^{\prime} \mathrm{E}$ ) is located in the north of Zhejiang Province, China. The samples were collected from four locations including Meishan Town (MS), the suburb of the County's urban area (SC), Hongqiao Town (HQ) and Lvshan Town (LS), respectively (see Figure 1). A large industrial 


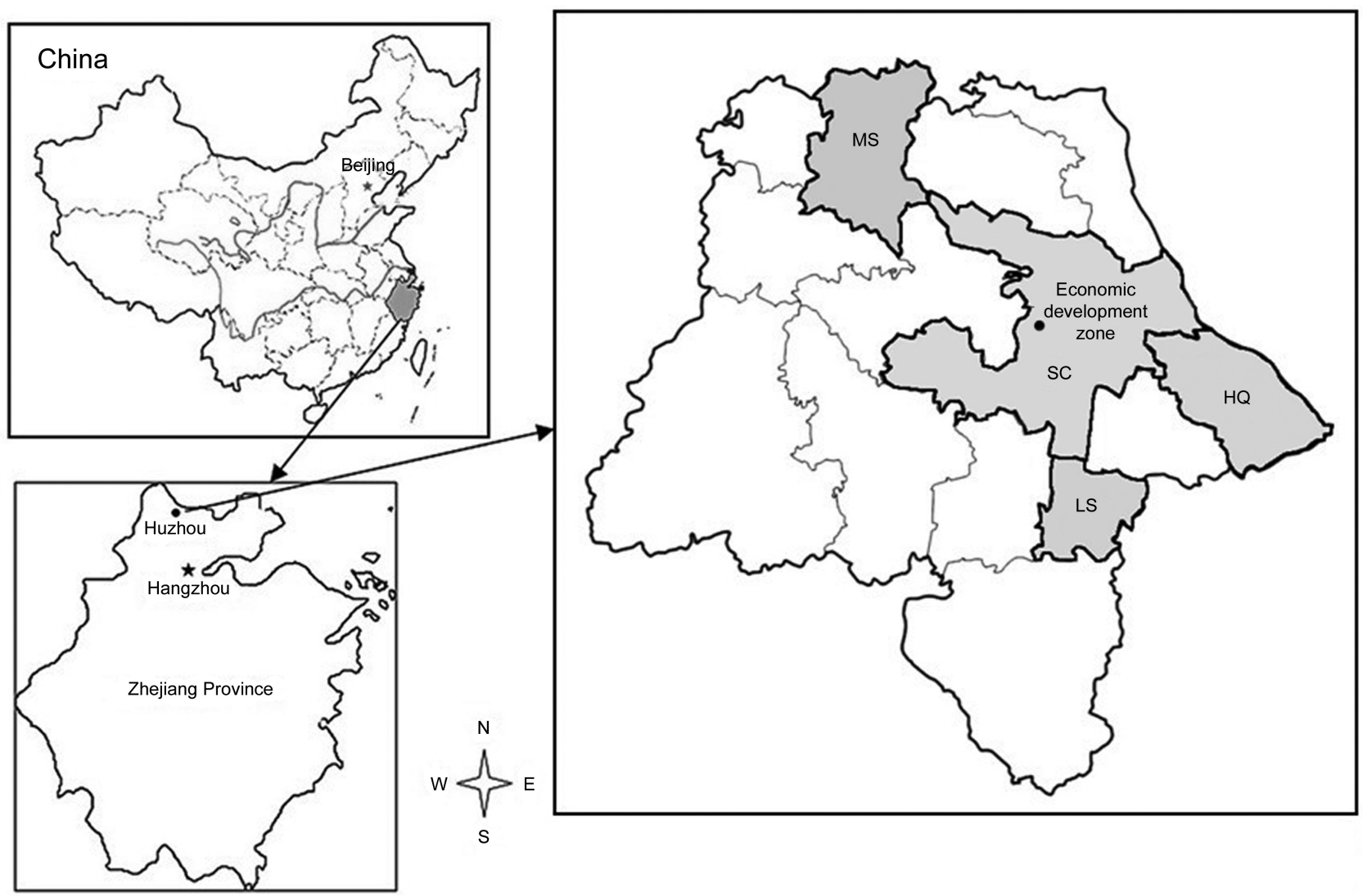

Figure 1 - Illustration of sampling sites in Changxing County, Zhejiang, China. MS: Meishan Town; SC: the suburb of the County's urban area; HQ\&LS: Hongqiao Town and Lvshan Town.

park consisting mainly of battery productions and refractory manufacturers was located in MS, representing areas seriously impacted by $\mathrm{Pb}$ and $\mathrm{Cr}$. SC was near a residential area and the economic development zone of Changxing, mainly polluted by domestic waste and small-scale industries. On the other hand, HQ and LS (called "HQ \& LS" henceforward) were both characterized as having "pollution-free vegetable production demonstration base", representing areas with relatively less heavy metal contamination.

\section{Collection and preparation of samples}

From Nov. 2011 to May 2012, eleven vegetable species, Brassica chinensis L. (green vegetable), Brassica campestris $L$. (Chinese cabbage), Spinacia oleracea (spinach), Allium tuberosum Rottler (garlic chives), Brassica oleracea L.var.capitata L. (cabbage), Capsicum annuum (pepper), Solanum lycopersicum (tomato), Solanum melongena L. (eggplant), Cucumis sativus Linn (cucumber), Pisum sativum Linn (garden pea), Vicia faba Linn (horsebean) were randomly collected. They were considered as representative of vegetable species commonly consumed in the area under study.

A total of 96 vegetable samples were gathered from three locations. The number of vegetable samples for each kind ranged from four to nine, depending on the amount of vegetables planted in the study area. Soil and vegetable samples were paired collected. Vegetables' rooted soil samples were taken at $0-20 \mathrm{~cm}$ in depth. A composite sample was composed of five subsamples at each sampling site for both vegetables and soils. All vegetables and soil samples were individually sealed into polyethylene bags to avoid cross-contamination and transferred to the laboratory on the same day of sampling (CMEP, 2004).

Only the edible part of each vegetable sample was used for analysis. The vegetable samples were washed with ultrapure water three times. After the water had evaporated, the vegetable samples were weighed, ovendried at $65^{\circ} \mathrm{C}$ for $48 \mathrm{~h}$, weighed again and then crushed into powder. The heavy metal concentrations in edible portions of vegetables were determined on a wet weight basis.

All soil samples were naturally air-dried until constant weight was reached. The dried soil samples were homogenized with pestle in a mortar, and then passed through standard sieves No.20 ( $\Phi 0.9 \mathrm{~mm}$ ), No.60 (Ф 0.3 $\mathrm{mm})$, No.100 ( $\Phi 0.15 \mathrm{~mm}$ ) for analysis of $\mathrm{pH}$, organic matter (OM) and heavy metal contents, respectively. Soil $\mathrm{pH}$ was measured using a $\mathrm{pH}$ electrode and the ratio 
of solid: water was 1:2.5 (SFA, 1987). OM contents of soil samples were determined using the loss on ignition method (Boyle, 2004; Heiri et al., 2001; Dean, 1974).

\section{Analysis}

For digestion of soils, a $0.2 \mathrm{~g}$ dried sample was digested with $9 \mathrm{~mL}$ concentrated $\mathrm{HNO}_{3}$ in a high borosilicate glass (HBG) vessel. The heating conditions were: $90{ }^{\circ} \mathrm{C}$ for $30 \mathrm{~min}, 110{ }^{\circ} \mathrm{C}$ for $30 \mathrm{~min}, 125^{\circ} \mathrm{C}$ for $1 \mathrm{~h}$. After cooling, $1 \mathrm{~mL} \mathrm{HClO}_{4}$ was added, and the mixture was again subjected to heating at $110^{\circ} \mathrm{C}$ for 30 min and at $130{ }^{\circ} \mathrm{C}$ for $1 \mathrm{~h}$ (Huang et al., 2007; USEPA, 1996). This method was not a total digestion technique. However, it was a very strong acid digestion that would dissolve almost all elements that were environmentally available.

Solutions were diluted to $25 \mathrm{~mL}$ with ultrapure water and transferred to a bottle after filtration. For vegetables, a $0.5 \mathrm{~g}$ dried sample was digested in $\mathrm{HNO}_{3}-\mathrm{HC}$ $1 \mathrm{O}_{4}$ mixture (9: 1) and the heating conditions were: $60^{\circ} \mathrm{C}$ for $2 \mathrm{~h}, 100{ }^{\circ} \mathrm{C}$ for $2 \mathrm{~h}, 125^{\circ} \mathrm{C}$ for $1 \mathrm{~h}$, and $175^{\circ} \mathrm{C}$ for $1 \mathrm{~h}$ (Ghosh et al., 2012). Total $\mathrm{Cr}, \mathrm{Cd}$ and $\mathrm{Pb}$ contents in the vegetable and soil samples were analyzed by inductively coupled-mass spectrometry (ICP-MS). The limits of detection (LOD) for vegetables and soils were as follows: $0.137 \mu \mathrm{g} \mathrm{L}^{-1}$ for $\mathrm{Cr}, 0.024 \mu \mathrm{g} \mathrm{L}^{-1}$ for $\mathrm{Cd}$, and $0.350 \mu \mathrm{g} \mathrm{L}^{-1}$ for $\mathrm{Pb}$. The coefficient of variation for triplicate analysis was $\leq 10 \%$. For quality control, certified reference material (GBW 10043) was used. The recovery rates ranged from $98 \%$ to $102 \%$.

\section{Statistical analysis}

Statistical analysis of data was carried out using Microsoft Office Excel 2010 and the SPSS 16.0 statistical package program. The Pearson correlation test was used to check for correlations between transfer factor (TF) values of heavy metals and soil properties $(\mathrm{pH}$, organic matter). Calculations of the distribution of dietary exposure to heavy metals via consumption of vegetables for the local population were performed using the commercially available software package @risk (Version 5.0, for excel professional edition, Palisade). The estimated daily intake dose (EDI) was calculated as follows:

$E D I=\frac{C_{i} \times I R}{B W}$

where $C_{i}\left(\mathrm{mg} \mathrm{kg}^{-1}\right)$ is the concentration of heavy metals in edible portions of vegetables $(i=\mathrm{Cr}, \mathrm{Cd}$ or $\mathrm{Pb}), I R$ ( $\mathrm{g}$ per day) the average daily consumption of vegetables, and $B W(\mathrm{~kg})$ the body weight.

\section{Results and Discussion}

All the analyzed vegetable samples contained detectable concentrations of total $\mathrm{Cr}, \mathrm{Cd}$ and $\mathrm{Pb}$ (Table 1). Mean concentrations (and range) of total $\mathrm{Cr}, \mathrm{Cd}$ and $\mathrm{Pb}$ in edible portions of vegetables were 2.354 (0.078$14.878), 0.035$ (0.003-0.230), and 0.039 (0.003-0.178) mg $\mathrm{kg}^{-1}$, respectively. The average concentrations of heavy metals in all vegetable samples were in the order of $\mathrm{Cr}$ $>\mathrm{Pb}>\mathrm{Cd}$. The coefficients of variation for the three heavy metals in vegetables also followed the same order, suggesting that $\mathrm{Cr}$ is more susceptible to the interference of vegetable species, pollution and other external factors.

According to Chinese food safety criteria, the maximum allowable concentrations (MAC) of $\mathrm{Cd}$ were 0.2 $\mathrm{mg} \mathrm{kg}^{-1}$ for leaf vegetables and leguminous vegetables and $0.05 \mathrm{mg} \mathrm{kg}^{-1}$ for melon vegetables and solanaceous vegetables $(\mathrm{CMH}, 2005)$. About $3 \%$ of the samples were above the MAC for $\mathrm{Cd}$ and the samples with elevated $\mathrm{Cd}$ levels were all found in MS. Additionally, the $\mathrm{Pb}$ concentrations observed in vegetable samples were all within the permissible limit.

The total $\mathrm{Cr}$ levels in edible portions of vegetables were much higher than those found in presumably less contaminated areas, such as Jiangsu, China $10.67 \mathrm{mg}$ $\mathrm{kg}^{-1}$ ) (Cao et al., 2010) and in Brazil (0.01-0.6 mg kg-1) (Guerra et al., 2012). Higher concentrations of total $\mathrm{Cr}$ in this region may be expected due to the mass production of refractory materials in Changxing County, especially in MS, where there are many refractory factories. For the concentrations of $\mathrm{Cd}$ in edible portions of vegetables,

Table 1 - Concentrations of heavy metals in edible portions of vegetables.

\begin{tabular}{|c|c|c|c|c|c|c|c|}
\hline \multirow{2}{*}{ Sampling areas } & \multirow{2}{*}{ Sample number } & \multicolumn{2}{|c|}{$\mathrm{Cr}$} & \multicolumn{2}{|c|}{$\mathrm{Cd}$} & \multicolumn{2}{|c|}{$\mathrm{Pb}$} \\
\hline & & Mean \pm SD & Range & Mean \pm SD & Range & Mean \pm SD & Range \\
\hline & & & & $\mathrm{mg}$ & & & \\
\hline MS & 31 & $1.645 \pm 1.902$ & $0.213-6.992$ & $0.059 \pm 0.060$ & $0.006-0.230$ & $0.047 \pm 0.049$ & $0.005-0.178$ \\
\hline SC & 30 & $2.871 \pm 4.239$ & $0.078-14.868$ & $0.030 \pm 0.045$ & $0.003-0.195$ & $0.040 \pm 0.041$ & $0.005-0.155$ \\
\hline HQ\&LS & 35 & $2.505 \pm 4.244$ & $0.177-14.878$ & $0.020 \pm 0.016$ & $0.005-0.061$ & $0.031 \pm 0.028$ & $0.003-0.104$ \\
\hline \multicolumn{2}{|l|}{ Standards } & \multicolumn{2}{|c|}{$\mathrm{Cr}$} & \multicolumn{2}{|c|}{$\mathrm{Cd}$} & \multicolumn{2}{|c|}{$\mathrm{Pb}$} \\
\hline & & & & $-m g$ & & & \\
\hline \multicolumn{2}{|l|}{ WHO/EU, 1983} & \multicolumn{2}{|c|}{0.1} & \multicolumn{2}{|c|}{0.01} & \multicolumn{2}{|c|}{5.0} \\
\hline \multicolumn{2}{|l|}{ FAO/WHO, 2001} & \multicolumn{2}{|c|}{-} & \multicolumn{2}{|c|}{$0.02-0.2$} & \multicolumn{2}{|c|}{$0.5-1.0$} \\
\hline \multicolumn{2}{|l|}{ CMH, 2005} & \multicolumn{2}{|c|}{$0.5-1.0$} & \multicolumn{2}{|c|}{$0.05-0.2$} & \multicolumn{2}{|c|}{$0.1-0.3$} \\
\hline
\end{tabular}

MS: Meishan Town; SC: the suburb of the County's urban area; HQ\&LS: Hongqiao Town and Lvshan Town; WHO: World Health Organization; EU: European Union; FAO: Food and Agriculture Organization; $\mathrm{CMH}$ : Chinese Ministry of Health; SD: Standard Deviation. 
the mean value of the three locations was $0.035 \mathrm{mg} \mathrm{kg}^{-1}$, which was in the same range as the results from Jiangsu, China (Cao et al., 2010) and Gejiu City, Yunnan Province, China (Xiao et al., 2011) and lower than the findings from Gaziantep, Turkey irrigated with municipal and industrial wastewaters (Avci, 2012).

Concentrations of $\mathrm{Cd}$ in vegetables grown in uncontaminated soils generally varied from 0.005 to $0.5 \mathrm{mg}$ $\mathrm{kg}^{-1}$, with levels being somewhat higher in leafy vegetables and in belowground tissues than in other plant tissues (Avci, 2012). The range of $\mathrm{Pb}$ concentrations (0.003-0.178 $\mathrm{mg} \mathrm{kg}^{-1}$ ) in edible portions of vegetables was comparable to the values found in Jiangsu, China (Cao et al., 2010). Plants grown on polluted sites could have a considerably high level of $\mathrm{Pb}$. Weldegebriel et al. (2012) reported $\mathrm{Pb}$ levels in vegetables varying from 0.11 to $0.89 \mathrm{mg} \mathrm{kg}^{-1}$, which was almost ten times higher than those in the present study.

The average total $\mathrm{Cr}$ concentrations in edible portions of vegetables of the three sampling locations were in the order SC > MS > HQ\&LS, while the average concentrations of $\mathrm{Cd}$ and $\mathrm{Pb}$ in edible portions of vegetables were in the following order: MS > SC > HQ\&LS. The differences in heavy metal concentrations in edible portions of vegetables from the three sampling locations were tested by One-Way ANOVA analysis ( $p=0.05$ ) There was no difference among the three locations for total $\mathrm{Cr}$ and $\mathrm{Pb}(p>0.05)$ though the concentrations of $\mathrm{Cd}$ in edible portions of vegetables from MS were higher than those from HQ\&LS ( $p<0.05)$. Meanwhile, no differences in $\mathrm{Cd}$ values were observed between MS and $\mathrm{SC}$ in this study $(p>0.05)$.

The maximum concentration of total $\mathrm{Cr}$ observed in horsebean surpassed the MAC by about 11 times, showing that the vegetables in the study area were severely contaminated by $\mathrm{Cr}$ (Figure 2). The concentrations of total $\mathrm{Cr}$ in horsebean and garden pea were higher than those in the other nine species of vegetables $(p<0.05)$. The mean total $\mathrm{Cr}$ values $\left(\mathrm{mg} \mathrm{kg}^{-1}\right)$ in the vegetables were in the following order: horsebean (10.644) $>$ garden pea (7.509) > eggplant $(1.315)>$ garlic chives (1.045) > pepper $(1.044)>$ cabbage $(0.951)>$ tomato

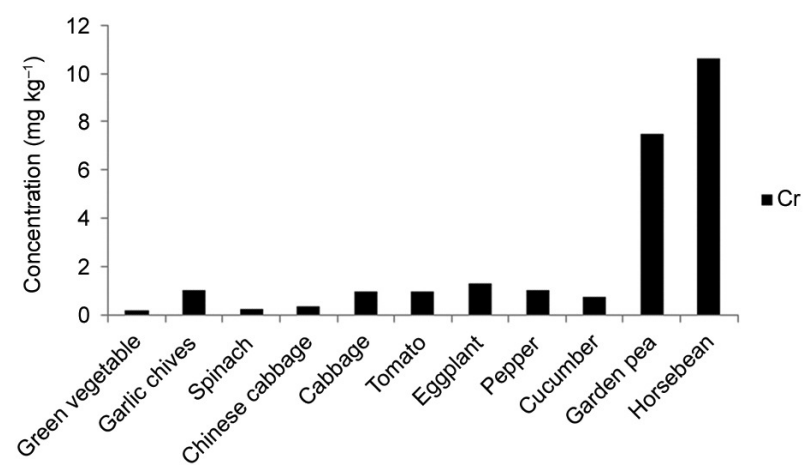

Figure 2 - Concentrations of $\mathrm{Cr}$ in edible portions of vegetables.
(0.947) > cucumber $(0.740)>$ Chinese cabbage (0.327) $>$ spinach $(0.243)>$ green vegetable (0.190). However, unlike $\mathrm{Cr}$, the maximum $\mathrm{Cd}$ and $\mathrm{Pb}$ levels were both found in spinach (Figure 3).

The average $\mathrm{Cd}$ content in spinach was 1.84 time the MAC. Cd values $\left(\mathrm{mg} \mathrm{kg}^{-1}\right)$ in the vegetables were in the following order: spinach $(0.092)>$ green vegetable $(0.073)>$ garlic chives $(0.055)>$ cabbage $(0.052)>$ Chinese cabbage $(0.035)>$ eggplant $(0.033)>$ garden pea (0.023) > horsebean (0.022) > pepper $(0.014)>$ tomato (0.012) > cucumber (0.005), while $\mathrm{Pb}$ values $\left(\mathrm{mg} \mathrm{kg}^{-1}\right)$ were in the following order: spinach $(0.113)>$ green vegetable $(0.106)>$ Chinese cabbage $(0.059)>$ garlic chives $(0.054)>$ garden pea $(0.054)>$ horsebean $(0.041)$ $>$ cabbage $(0.025)>$ eggplant $(0.012)>$ tomato $(0.009)$ $>$ pepper (0.007) > cucumber (0.006).

In general, the level of acceptance of $\mathrm{Pb}$ in vegetables was more consistent with those of $\mathrm{Cd}$ than $\mathrm{Cr}$. Leguminous vegetables were more likely to accumulate $\mathrm{Cr}$, while leaf vegetables tended to show higher concentrations of both $\mathrm{Cd}$ and $\mathrm{Pb}$. Melon vegetables displayed a relatively tendency to accumulate these three heavy metals. This was similar to the finding that more metals accumulated in leaf vegetables, namely, $\mathrm{Cd}$ and $\mathrm{Pb}$ (Ghosh et al., 2012).

The trends of the total heavy metals in soils were in the following descending order: $\mathrm{Cr}>\mathrm{Pb}>\mathrm{Cd}$ (Table 2). The mean total $\mathrm{Cr}$ value in soils from HQ\&LS was a little higher than those from SC and MS. In only one of the 96 soil samples was $\mathrm{Cr}$ found where concentration exceeded the maximum permissible level of $150 \mathrm{mg} \mathrm{kg}^{-1}$ set by Chinese Environmental Quality for Soils (NEPAC, 1995). The contents of $\mathrm{Cd}$ varied in a range of $0.52-1.61$, 0.18-1.41 and 0.23-0.57 $\mathrm{mg} \mathrm{kg}^{-1}$ for MS, SC and HQ\&LS, respectively, with $68 \%$ of the samples in the three locations higher than the threshold value (when $\mathrm{pH} \leq 7.5$, $0.3 \mathrm{mg} \mathrm{kg}^{-1}$ for $\mathrm{Cd} ; \mathrm{pH}>7.5,0.6 \mathrm{mg} \mathrm{kg}^{-1}$ for $\mathrm{Cd}$ ). The mean (and range) concentrations of $\mathrm{Pb}$ in soil samples were 71.63 (39.20-340.54) $\mathrm{mg} \mathrm{kg}^{-1}$ in MS, 31.74 (17.74$87.82) \mathrm{mg} \mathrm{kg}^{-1}$ in SC, 29.03 (19.72-67.19) $\mathrm{mg} \mathrm{kg}^{-1}$ in HQ\&LS, respectively. The concentrations of $\mathrm{Pb}$ in all the soil samples were below the permissible limit.

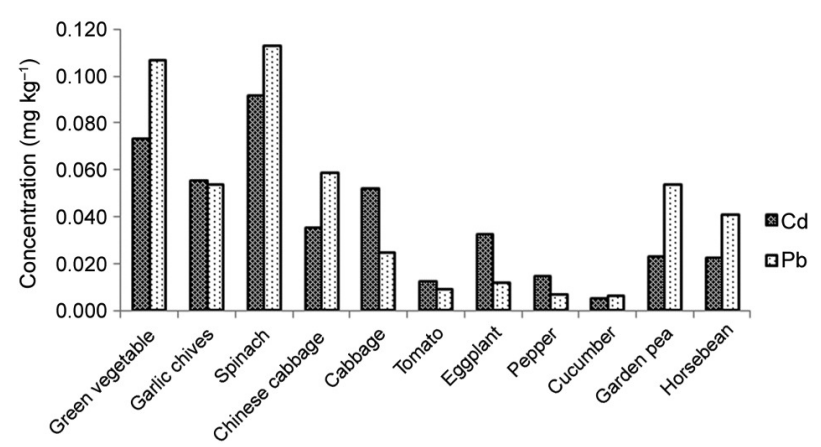

Figure 3 - Concentrations of $\mathrm{Cd}$ and $\mathrm{Pb}$ in edible portions of vegetables. 
The transfer of heavy metals from soils to vegetables was dependent on the vegetable species (Figures 4,5 and 6). The highest average $\mathrm{TF}$ values of $\mathrm{Cr}, \mathrm{Cd}$ and $\mathrm{Pb}$ were observed in horsebean, green vegetables and green vegetables, respectively. $\mathrm{Cr}$ had the highest $\mathrm{TF}$ values followed by $\mathrm{Cd}$ and then $\mathrm{Pb}$, suggesting that $\mathrm{Cr}$ was the most bio-available. Heavy metals in soils can be

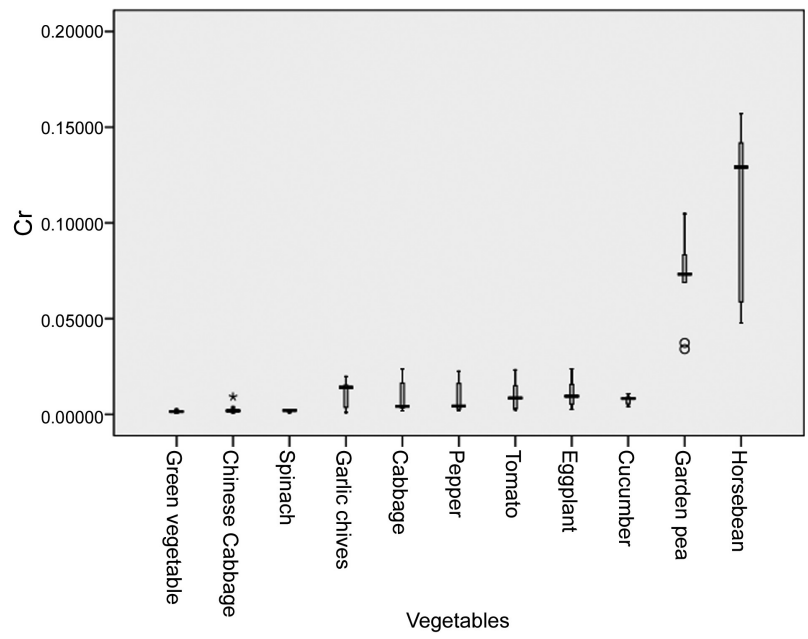

Figure 4 - The transfer factors (TF) values of $\mathrm{Cr}$ in vegetables.

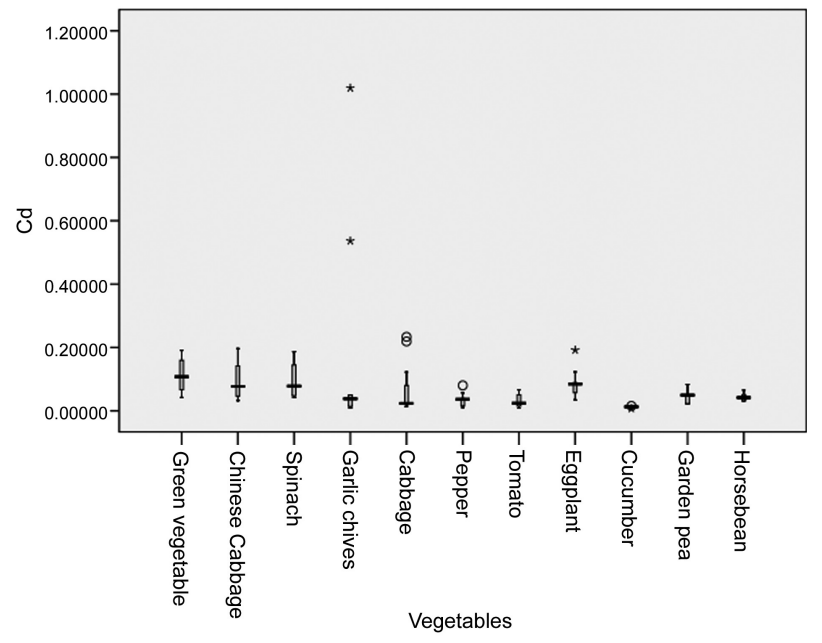

Figure 5 - The TF values of $\mathrm{Cd}$ in vegetables. absorbed and utilized by plants in two forms: (i) dissolving in soil solution, and (ii) exchangeable in organic and inorganic components (Aydinalp and Marinova, 2003). Furthermore, plant uptake of heavy metals depends mainly on the mobility and availability of heavy metals in soils. Among soil properties, soil pH had the greatest impact on the desorption and bioavailability of heavy metals, because of its strong effects on solubility and speciation of heavy metals both in the soil as a whole and particularly in the soil solution (Müehlbachová et al., 2005).

Apart from soil $\mathrm{pH}, \mathrm{OM}$ was also one of the most important properties affecting heavy metal availability in soils for retaining heavy metals in an exchangeable form (Zeng et al., 2011). Therefore, the effect of soil pH and OM on the uptake of heavy metals by vegetables was considered in this study (Table 3); TF values for three heavy metals were all negatively correlated with soil $\mathrm{pH}$ and positively correlated with soil OM. The mobility and uptake of heavy metals to vegetables increased with decreasing soil $\mathrm{pH}$ and increasing OM. A negative correlation between heavy metal mobility and availability and soil $\mathrm{pH}$ has been reported in numerous studies (Sukreeyapongse et al., 2002; Bang and Hesterberg, 2004; Wang et al., 2006; Ghosh et al., 2012). It has also been reported that heavy metal adsorption declined with decreasing OM in soils (Almas and Singh, 2001; Xue et al., 2012).

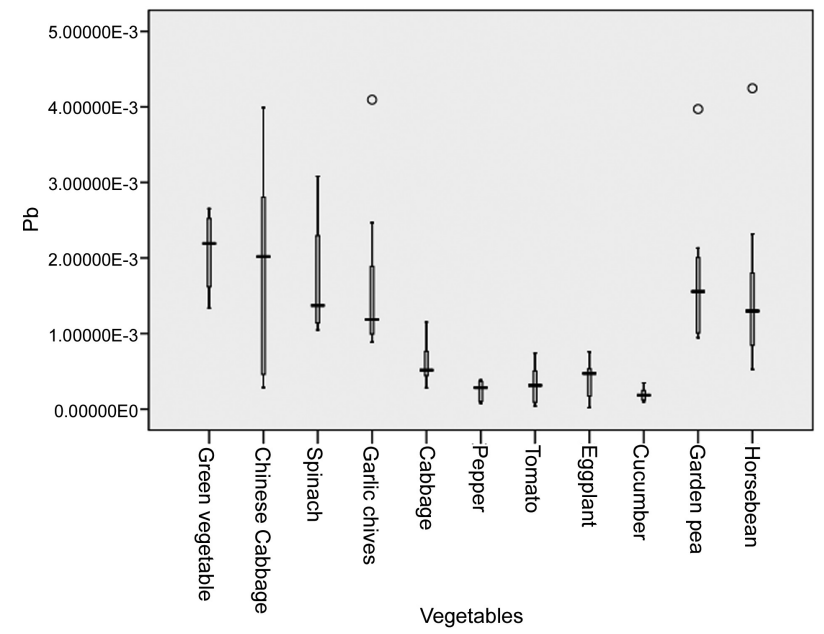

Figure 6 - The TF values of $\mathrm{Pb}$ in vegetables.

Table 2 - Chemical and physical attributes of soil.

\begin{tabular}{|c|c|c|c|c|c|c|}
\hline & \multicolumn{2}{|c|}{ MS } & \multicolumn{2}{|c|}{ SC } & \multicolumn{2}{|c|}{ HQ\&LS } \\
\hline & Mean \pm SD & Range & Mean \pm SD & Range & Mean \pm SD & Range \\
\hline $\mathrm{Cr}\left(\mathrm{mg} \mathrm{kg}^{-1}\right)$ & $104.12 \pm 17.90$ & $76.95-142.32$ & $109.41 \pm 17.56$ & $78.73-156.92$ & $118.96 \pm 16.03$ & $96.73-143.85$ \\
\hline $\mathrm{Cd}\left(\mathrm{mg} \mathrm{kg}^{-1}\right)$ & $0.89 \pm 0.27$ & $0.52-1.61$ & $0.40 \pm 0.27$ & $0.18-1.41$ & $0.37 \pm 0.10$ & $0.23-0.57$ \\
\hline $\mathrm{Pb}\left(\mathrm{mg} \mathrm{kg}^{-1}\right)$ & $71.63 \pm 55.21$ & $39.20-340.54$ & $31.74 \pm 19.80$ & $17.42-87.82$ & $29.03 \pm 7.49$ & $19.72-67.19$ \\
\hline $\mathrm{pH}$ & $6.06 \pm 1.17$ & $4.61-8.34$ & $6.85 \pm 1.06$ & $5.11-9.62$ & $6.15 \pm 1.09$ & $4.27-8.13$ \\
\hline OM (\%) & $5.11 \pm 1.23$ & $2.44-7.52$ & $6.39 \pm 1.68$ & $4.12-11.22$ & $7.14 \pm 0.78$ & $5.96-9.74$ \\
\hline
\end{tabular}

MS: Meishan Town; SC: the suburb of the County's urban area; HQ\&LS: Hongqiao Town and Lvshan Town; OM: Organic Matter; SD: Standard Deviation. 
Table 3 - Correlations between TF values of heavy metals and soil $\mathrm{pH}, \mathrm{OM}$ values.

\begin{tabular}{lccc}
\hline & TF for $\mathrm{Cr}$ & TF for $\mathrm{Cd}$ & $\mathrm{TF}$ for $\mathrm{Pb}$ \\
\hline $\mathrm{pH}$ & -0.101 & -0.097 & -0.185 \\
$\mathrm{OM}$ & 0.321 & 0.072 & 0.157 \\
\hline
\end{tabular}

TF: Transfer factor; OM: Organic Matter.

According to the Agro-geology Environment Survey in Zhejiang, the soil acidification trend and the decrease in soil organic matter in the northern part of Zhejiang were bound to increase the accumulation of heavy metals in agro-products (Pan et al., 2007). Therefore, much attention should be paid to the excessive accumulation of heavy metals in agro-products caused by soil environment change (Pan et al., 2007).

Based on the Chinese nutrition and health survey (Wang, 2002), the average daily consumption of vegetables was $276.2 \mathrm{~g}$ per day for adults, and their average body weight was $58.7 \mathrm{~kg}$. The average concentrations of total $\mathrm{Cr}, \mathrm{Cd}$, and $\mathrm{Pb}$ in edible portions of vegetables in this study were $2.354,0.035,0.039 \mathrm{mg} \mathrm{kg}^{-1}$, respectively. Then the EDI values of $\mathrm{Cr}, \mathrm{Cd}$ and $\mathrm{Pb}$ were calculated to be $0.011,1.65 \times 10^{-4}$ and $1.84 \times 10^{-4} \mathrm{mg} \mathrm{kg}^{-1}$ per day, respectively. The daily intake of heavy metals $(\mathrm{Pb}, \mathrm{Cd}$ and $\mathrm{Cr})$ depends on both the concentration of heavy metals in edible portions of vegetables and the associated consumption data. Additionally, body weight can influence the tolerance of pollutants.

The reference dose (RfD) for $\mathrm{Cr}$ and Cd were set by the USEPA (USEPA, 1998) at 1.5 and $1 \times 10^{-3} \mathrm{mg}$ $\mathrm{kg}^{-1}$ per day, respectively and the RfD for $\mathrm{Pb}$ was set by JECFA (JECFA, 2003) at $3.6 \times 10^{-3} \mathrm{mg} \mathrm{kg}^{-1}$ per day. The EDIs of $\mathrm{Cr}, \mathrm{Cd}$ and $\mathrm{Pb}$ were all far below the RfDs, suggesting that the consumption of vegetables posed negligible health risk to the local population. However, vegetables only accounted for a part of the human diet. Other food, such as grain, seafood and livestock, might contain higher levels of heavy metals, which could significantly increase the risk of ingestion of heavy metals by the local population. Moreover, considerable attention should also be paid to the potential health risk of heavy metals via other exposure pathways.

\section{Conclusions}

$\mathrm{Pb}$ levels in all samples were within national food safety criteria, while $\mathrm{Cd}$ concentration in $3 \%$ of vegetable samples exceeded MAC according to the criteria. The transfer of heavy metals from soils to vegetables was dependent on vegetable species. Leguminous vegetables were more likely to accumulate $\mathrm{Cr}$, while leaf vegetables tended to demonstrate higher concentrations of $\mathrm{Cd}$ and $\mathrm{Pb}$. Melon vegetables had a relatively low tendency to accumulate these three heavy metals. Transfer factors from soils to vegetables were positively correlated with soil $\mathrm{OM}$ and negatively correlated with soil $\mathrm{pH}$. Thus, the potential health risks posed by $\mathrm{Cr}, \mathrm{Cd}$ and $\mathrm{Pb}$ were considered negligible based on the results of EDI, indicating that it remained safe for the local population in Changxing County to consume vegetables.

\section{Acknowledgements}

To the Special Fund for Agro-scientific Research in the Public Interest, for financial support (200903009), and to the Zhejiang Provincial Natural Science Foundation of China (LY13B070003).

\section{References}

Adriano, D.C. 2001. Trace Elements in Terrestrial Environments. 2ed. Springer-Verlag, New York, NY, USA.

Almas, A.R.; Singh B.R. 2001. Plant uptake of cadmium-109 and zinc-65 at different temperature and organic matter levels. Journal of Environmental Quality 30: 869-877.

Avci, H. 2012. Trace metals in vegetables grown with municipal and industrial wastewaters. Toxicological \& Environmental Chemistry 94: 1125-1143.

Aydinalp, C.; Marinova, S. 2003. Distribution and forms of heavy metals in some agricultural soils. Polish Journal of Environmental Studies 12: 629-633.

Bang, J.S.; Hesterberg, D. 2004. Dissolution of trace element contaminants from two coastal plain soils as affected by $\mathrm{pH}$. Journal of Environmental Quality 33: 891-901.

Boyle, J. 2004. A comparison of two methods for estimating the organic matter content of sediments. Journal of Paleolimnology 31: $125-127$

Cao, H.B.; Chen, J.J.; Zhang, J.; Zhang, H.; Qiao, L.; Men, Y. 2010. Heavy metals in rice and garden vegetables and their potential health risks to inhabitants in the vicinity of an industrial zone in Jiangsu, China. Journal of Environmental Sciences 22: 17921799.

Chinese Ministry of Environmental Protection [CMEP]. 2004. The Technical Specification for Soil Environmental Monitoring CMEP, Beijing, China. HJ/T 166-2004.

Chinese Ministry of Health [CMH]. 2005. Maximum Levels of Contaminants in Foods. CMH, Beijing, China. GB2762-2005.

Dean, W.E. 1974. Determination of carbonate and organicmatter in calcareous sediments and sedimentary-rocks by loss on ignition-comparison with other methods. Journal of Sedimentary Petrology 44: 242-248.

Dong, J.; Yang, Q.W.; Sun, L.N.; Zeng, Q.; Liu, S.J.; Pan, J.; Liu, X.L. 2011. Assessing the concentration and potential dietary risk of heavy metals in vegetables at a $\mathrm{Pb} / \mathrm{Zn}$ mine site, China. Environmental Earth Science 64: 1317-1321.

Food and Agriculture Organization [FAO]. 2001. Codex Alimentarius Commission Food Additives and Contaminants. FAO/WHO, Rome, Italy. ALINORM 01/12A: 1-289.

Ghosh, A.K.; Bhatt, M.A.; Agrawal, H.P. 2012. Effect of longterm application of treated sewage water on heavy metal accumulation in vegetables grown in Northern India Environmental Monitoring and Assessment 184: 1025-1036.

Guerra, F.; Trevizam, A.R.; Muraoka, T.; Marcante, N.C.; Canniatti-Brazaca, S.G. 2012. Heavy metals in vegetables and potential risk for human health. Scientia Agricola 69: 54-60. 
Heiri, O.; Lotter, A.F.; Lemcke, G. 2001. Loss on ignition as a method for estimating organic and carbonate content in sediments: reproducibility and comparability of results. Journal of Paleolimnology 25: 101-110.

Huang, Z.W.; Wang, X.; Qiu, H.Y.; Chen, L.D.; Zeng, M. 2007. Comparison of microwave digestion and electric heating board digestion in determining heavy metals content in soils. Journal of Xiamen University 46: 103-106 (in Chinese, with abstract in English).

JECFA. 2003. Report of the $34^{\text {th }}$ Session of Codex Committee on Food Additives and Contaminants. Joint FAO/WHO Food Standards Programme Codex Alimentarius Commission, Rotterdam, Netherlands.

Li, Y.; Wang, Y.B.; Gou X.; Su, Y.B.; Wang, G. 2006. Risk assessment of heavy metals in soils and vegetables around non-ferrous metals mining and smelting sites, Baiyin, China. Journal of Environmental Sciences-China 18: 1124-1134.

Liu, C.P.; Luo, C.L.; Gao, Y.; Li, F.B.; Lin, L.W.; Wu, C.A.; Li, X.D. 2010. Arsenic concentration and potential health risk implications at an abandoned tungsten mine, southern China. Environmental Pollution 158: 820-826.

Müehlbachová, G.; Simon, T.; Pechova, M. 2005. The availability of $\mathrm{Cd}, \mathrm{Pb}$ and $\mathrm{Zn}$ and their relationships with soil $\mathrm{pH}$ and microbial biomass in soils amended by natural clinoptilolite. Plant Soil and Environment 51: 26-33.

National Environmental Protection Agency of China [NEPAC]. 1995. Environmental quality standard for soils.. NEPAC, Beijing, China. GB15618-1995.

Nordic Council of Ministers [NCM]. 2003. Lead review. Available at: http://www.who.int/ifcs/docum-ents/forums/forum5/nmr_ lead.pdf [Accessed Jun 8, 2011]

Pan, S.M.; Zhou, G.H.; Dong, Y.X.; Zhang, J.M. 2007. Soil eco-geochemical research. p. 111-131. In: Methodology of assessment on agro-geology environment survey in Zhejiang. Geology Press, Beijing, China.

Qian, Y.Z.; Chen, C.; Zhang, Q.; Li, Y.; Chen, Z.J.; Li, M. 2010. Concentrations of cadmium, lead, mercury and arsenic in Chinese market milled rice and associated population health risk. Food Control 21: 1757-1763.

State Forestry Administration [SFA]. 1987. Determination of $\mathrm{pH}$ Value in Forest Soil. SFA, Beijing, China. GB7589-87.

Sipter, E.; Rozsa, E.; Gruiz, K.; Tatrai, E.; Morvai, V. 2008. Sitespecific risk assessment in contaminated vegetable gardens. Chemosphere 71: 1301-1307.

Sukreeyapongse, O.; Holm, P.E.; Strobel, B.W.; Panichsakpatana, S.; Magid, J.; Hansen, H.C.B. 2002. pH-dependent release of cadmium, copper, and lead from natural and sludge-amended soils. Journal of Environmental Quality 31: 1901-1909.

Tripathi, R.M.; Raghunath, R.; Krishnamoorthy, T.M. 1997. Dietary intake of heavy metals in Bombay city, India. Science of the Total Environment 208: 149-159.

United Nations Environment Programme [UNEP]. 2006. Interim review of scientific information on cadmium. Available at: http://www.unepchemicals.ch/pb_and_cd/SR/Files/Interim_ reviews/UNEP_Cadmium_review_Interim_Oct.2006.pdf [Accessed Jun. 15, 2011]
United States Environmental Protection Agency [USEPA]. 1980. Health Assessment Document for Chromium. USEPA, Washington, DC, USA.

United States Environmental Protection Agency [USEPA]. 1996. Method 3050B: Acid Digestion of Sediments, Sludge, and Soils. USEPA, Washington, DC, USA.

United States Environmental Protection Agency [USEPA]. 1998. Toxicological review of trivalent chromium. In: Support of summary information on the Integrated Risk Information System (IRIS). USEPA, Washington, DC, USA.

Wang, A.S.; Angle, J.S.; Chaney, R.L.; Delorme, T.A.; Reeves, R.D. 2006. Soil pH effects on uptake of $\mathrm{Cd}$ and $\mathrm{Zn}$ by Thlaspi caerulescens. Plant and Soil 281: 325-337.

Wang, L.D. 2002. Chinese Nutrition and Health Survey Report: A Comprehensive Report in 2002. CHNS, Beijing, China.

Wang, Y.C.; Qiao, M.; Liu, Y.X.; Zhu, Y.G. 2012. Health risk assessment of heavy metals in soils and vegetables from wastewater irrigated area, Beijing-Tianjin city cluster, China. Journal of Environmental Sciences-China 24: 690-698.

Wang, Z.X.; Chen, J.Q.; Chai, L.Y.; Yang, Z.H.; Huang, S.H.; Zheng, Y. 2011. Environmental impact and site-specific human health risks of chromium in the vicinity of a ferro-alloy manufacturer, China. Journal of Hazardous Materials 190: 980985.

Weldegebriel, Y.; Chandravanshi, B.S.; Wondimu, T. 2012. Concentration levels of metals in vegetables grown in soils irrigated with river water in Addis Ababa, Ethiopia. Ecotoxicology and Environmental Safety 77: 57-63.

World Health Organization Regional Office for Europe [WHO/ EU]. 1983. WHO and EU Drinking Water Quality Guidelines For Heavy Metals and Threshold Values Leading to Crop Damage. WHO/EU, Geneva, Switzerland.

Xiao, Q.Q.; Wang, H.B.; Zhao, B.; Ye, Z.H. 2011. Heavy metal pollution in crops growing in suburb of Gejiu City, Yunnan Province, China: present situation and health risk. Journal of Agro-Environment Science 30: 271-281 (in Chinese, with abstract in English).

Xue, Z.J.; Liu, S.Q.; Liu, Y.L.; Yan, Y.L. 2012. Health risk assessment of heavy metals for edible parts of vegetables grown in sewage-irrigated soils in suburbs of Baoding City, China. Environmental Monitoring and Assessment 184: 35033513.

Yeganeh, M.; Afyuni, M.; Khoshgoftarmanesh, A.-H.; Soffianian, A.-R.; Schulin R. 2012. Health risks of metals in soil, water, and major food crops in Hamedan Province, Iran. Human and Ecological Risk Assessment 18: 547-568.

Zeng, F.R.; Ali, S.; Zhang, H.T.; Ouyang, Y.N.; Qiu, B.Y.; Wu, F.B.; Zhang, G.P. 2011. The influence of $\mathrm{pH}$ and organic matter content in paddy soil on heavy metal availability and their uptake by rice plants. Environmental Pollution 159: 84-91. 